\title{
Repurposing the university in the 21st century : Toward a progressive global vision
}

\section{Patomäki, Heikki Olavi}

2019-07-29

Patomäki , H O 2019 , ' Repurposing the university in the 21st century : Toward a progressive global vision ', Globalizations , vol. 16 , no. 5 , pp. 751-762 . https://doi.org/10.1080/14747731.2019.157

http://hdl.handle.net/10138/303890

https://doi.org/10.1080/14747731.2019.1578533

submittedVersion

Downloaded from Helda, University of Helsinki institutional repository.

This is an electronic reprint of the original article.

This reprint may differ from the original in pagination and typographic detail.

Please cite the original version. 


\title{
Repurposing the University in the 21st Century: Toward a Progressive Global Vision
}

\author{
Heikki Patomäki \\ Faculty of Social Sciences, University of Helsinki ${ }^{1}$
}

\begin{abstract}
The purpose of the contemporary university has been redefined across the world in terms of success in global competition, usefulness for money-making, and efficiency, meaning application of New Public Management ideas. My aim is to sketch an alternative and future-oriented ethico-political conception of the university to serve counterhegemonic purposes. First I discuss briefly the Humboldtian myth and legacy. Second, I summarise Jürgen Habermas's analysis of the historical and practical limits of the idea of the university. Third, in response to Habermas's criticism, I outline a non-speculative, scientific realist way of understanding the unity of all sciences and humanities. Fourth, I locate the idea of the university in the 21 st century global context, understood in part as world risk society. And finally, I argue that the autonomy of the university should be anchored in the rules, principles and institutional arrangements of multi-spatial metagovernance, rather than just those of territorial states. The future of the university calls for new cosmopolitan institutional solutions and world citizenship.
\end{abstract}

Keywords: collective learning, emergence, future, Humboldt, neoliberalism, university, world risk society

\section{Introduction}

Since the 1970s and 80s, national systems of higher education and research have gone through profound transformation. This transformation began in the Englishspeaking world and has barely left any part of the world unaffected. Universities have been repurposed in a rather uniform way across the world (Mittelman, 2018). In a world dominated by big corporations, CEOs and other members of the transnational managerial class, together with their associated cohorts in international organizations and state bureaucracies, have succeeded in remaking the universities to their own image. Economic utilitarianism and the supposed efficiency of hierarchical corporate management have largely replaced higher ideals and aspirations such as collective

\footnotetext{
${ }^{1}$ Correspondence Address: Heikki Patomäki, Faculty of Social Sciences, University of Helsinki, P.O. Box 54, Unioninkatu 37, Helsinki 00014, Finland. Email: heikki.patomaki@ helsinki.fi.
} 
learning, academic freedom, and democratic citizenship, or education understood in terms of self-cultivation and personal and cultural maturation.

This transformation has been a global process (Patomäki, 2005; Canaan \& Shuman, 2008; Mittelman, 2016). It is not only that universities have been have been restructured to accord with the ideas of New Public Management (NPM) and repurposed in a rather similar way worldwide. The process of repurposing has involved transnational standard-setting actors and processes such as global governance institutions (e.g. World Bank, WTO, OECD); accreditors and rankers (e.g. the Shanghai Jiao Tong University Institute of Higher Education Academic Ranking of World Universities); and transnationally networked corporate philanthropies, research institutes, think tanks and consultancy firms (e.g. Ford Foundation, business management studies centres, McKinsey \& company). By appealing to the wider economic narratives of globalisation, competitiveness and the knowledge-based economy, universities have been made (i) to compete against each other, especially in terms of rankings and other indicators that affect funding, and (ii) serve the competitiveness of corporations and states (Sum \& Jessop, 2013).

Although universities all over the world have been part of the same geo-historical process of transformation, local conditions vary and different spatio-temporalities can coexist even when they coalesce. For instance, James H. Mittelman (2018, ch.5) discusses the Finnish system under the heading of "retrenched social democracy", largely because there are still no tuition fees except now for non-EU students. In addition, the Finnish students receive financial aid and subsidies for living. The direction of change has nonetheless been the same as everywhere else. The management by performance system was established in 1999. Extra auditing systems were formed to monitor teaching, research, administration and their quality control systems. A new salary system, based on the idea of stimulating efforts through constant surveillance and carrots and sticks, was introduced in 2004-5. Five years later, Finnish universities were either partly or wholly privatised, depending on the university. Tenure-protection was abolished. The remaining democratic councilsystem of decision-making was replaced with a hierarchical top-down system of "professional" management. In the 2010s, universities have faced major budget cuts also many professors has been made redundant. University activities have been outsourced or incorporated. Students have been redefined as customers; internal user charges are widely applied; and external research funding has become a top priority.

The somewhat surprising absence of student fees is a feature inherited from the previous era. Since the mid-2000s, tuition fees have been suggested repeatedly. This aspect of the transformation process has become elongated because of resistance and prevalent public opinion. It took more than a decade and a right-wing government to establish fees for non-EU students in 2017. It seems rather unlikely that the next government will be capable or willing to extend fees to EU-students. 
Resistance to neoliberalisation has been widespread, but it has rarely been directed against global standard-setting actors and processes. For instance, German universities have collaborated in refusing to provide ranking-data, but their activism has been mainly targeted at the Germany-based Center for Higher Education Development. Most critics seem to take global networks, actors and processes as part of a given background. As George Turner, a columnist on educational policy with the Berlin daily Tagesspiegel, explains: "I don't see any sense in a prolonged [German] boycott of rankings". He continues: "It's the universities that will suffer because rankings are a fact of life and they influence government decision-making, whether we like it or not". Indirectly, however, Turner recognises the role of governments in the social construction of worldwide competition among the universities.

The purpose of the contemporary university has thus been redefined in terms of success in global competition, usefulness for money-making, and efficiency, meaning application of NPM ideas (about the theoretical origins of these ideas, see Gruening, 2001). The aspiration of every university is to be highly ranked, but what may be possible for a few actors is not possible for many simultaneously. The game is zero sum: if one university rises, another must decline. Formal rankings are empty of collective purpose. Likewise, profit-making in the capitalist market economy is often likened to a war (Shaikh, 2016). While it is possible for many actors' profits to be increased simultaneously, and while competition may generate for example technological dynamism, increases of profit can also be achieved at the expense of others (firms, workers, consumers, nature etc). Similarly, the imitation of the corporate management model is not supposed to be valuable as such; its justification is instrumentalist and based on supposed efficiency gains.

The university has thus been repurposed, but this purpose seems devoid of anything valuable in itself. It is true, of course, that competitiveness can be taken as a sign for achieving something good, but that good would have to be explained and justified separately. Even the idea of human capital in a knowledge-based economy is instrumentalist and tends to mean "true is whatever works economically" (Lorenz, 2006, p.3). Moreover, in the absence of a sweeping belief in efficient markets (in the broadest sense, see e.g. Soros, 2013; Patomäki, 2018a), capital or profit-making can hardly be taken as an unequivocal indicator of good understood for instance as aggregate welfare ${ }^{3}$ or, more generally, human flourishing (Sayer, 2011). Last but not

\footnotetext{
${ }^{2}$ Quoted in "Rankings boycott in Germany", by Frances Mechan Schmidt for Times Higher Education, March 21, 2013, Inside Higher Ed, available at https://www.insidehighered.com/news/2013/03/21/academics-germany-rebelagainst-rankings-system.

${ }^{3}$ Even in standard textbook terms of neoclassical economics, it is impossible to get from profits to aggregate welfare without specifying many counterfactual conditions such as the absence of externalities. If externalities characterise most markets and are pervasive, profits can hardly ever be good indicators of overall welfare. In neoclassical economics, value premises are implicit and measures such as Pareto-optimality, social welfare function, and an equitable Paretoefficient outcome are typically represented as technical rather than ethico-political
} 
least, corporate hierarchies in universities can only be justified, if at all, as efficient means to something else - such as success in ranking competition.

What follows is an outline for a possible substantial purpose for the $21^{\text {st }}$ century university. My aim is to sketch an alternative and future-oriented ethico-political conception of the university to serve counterhegemonic purposes. First I discuss briefly the Humboldtian myth and legacy. Second, I summarise Jürgen Habermas's analysis of the historical and practical limits of the idea of the university. Third, in response to Habermas's criticism, I outline a non-speculative, scientific realist way of understanding the unity of all sciences and humanities. Fourth, I locate the idea of the university in the $21^{\text {st }}$ century global context, understood in part as world risk society. And finally, I argue that the autonomy of the university should be anchored in the rules, principles and institutional arrangements of multi-spatial metagovernance, rather than just those of territorial states. The future of the university calls for new cosmopolitan institutional solutions and world citizenship.

\section{The Humboldtian legacy}

All modern traditions are invented and tend to involve mythical aspects. The concept of Humboldtian university emerged at the turn of the $19^{\text {th }}$ and $20^{\text {th }}$ centuries and has been used in discussions about and struggles over the future of the university (Ash, 2006). The Prussian scholar and statesman Wilhelm von Humboldt (1767-1835), who co-founded the University of Berlin in 1809, was in his own time better known as a linguist. The University of Berlin established a model that was later followed in many other places, but this model was based on ideas that were widely circulated during the Age of Enlightenment, the tradition of which was continued by Romanticism and other movements in the $19^{\text {th }}$ century. Moreover, the University of Berlin was not particularly unique in its institutional principles. Relatively free research already prospered in many European academies of science. The University of Göttingen, founded in 1734, had established the freedom of teaching. Humboldt studied at Göttingen and adopted many ideas from there.

It should come as no surprise that neither the invented tradition nor actual geohistorical realities accord fully with the ideas expressed in Humboldt's founding text "On the Internal and External Organization of the Higher Scientific Institutions in Berlin" (1810). ${ }^{4}$ For instance, Humboldt maintained a distinction between academies and universities. Whereas the former are entirely free to engage in research the way they deem best, and appoint their own members, "the university stands always in a

\footnotetext{
${ }^{4}$ Humboldt's now famous note "On the Internal and External Organization of the Higher Scientific Institutions in Berlin" was discovered in 1896 and published in 1903. Its publication was an important moment in the establishment of the Humboldt myth. An English translation of this five-page text is available at the German History in Documents and Images (GHDI) site: http://ghdi.ghi-dc.org/sub_document.cfm?document_id=3642.
} 
closer relationship to practical life and the needs of the state, since it always undertakes practical affairs for it, the guidance of the youth". Humboldt concluded that the appointment of university teachers must be reserved exclusively to the state. ${ }^{5}$

The invention of "the Humboldtian tradition" coincided with the rise of big science and increasing student numbers. Its invented nature does not imply irrelevance. Principles such as freedom of teaching and learning; the unity of teaching and research; the unity of science and humanist scholarship; and the primacy of "pure" science over specialised professional training set the basis for university institutions and guided practices throughout the $19^{\text {th }}$ century, especially in the German-speaking world and its surroundings. Not least because of the apparent success of German science and humanities, many countries looked to Germany as a model for the modernisation of their university systems in the 19th and early 20th centuries. This is also what American elite universities such as Harvard, Yale, and Johns Hopkins did. The US system may have been diverse and largely oriented toward vocational training, but the US emerged as the centre of science and scholarship following the relatively widespread adoption of "the Humboldtian principles" in its research universities - and after the catastrophic rise of power of Adolf Hitler in 1933, which led to an influx of central-European scientists and scholars to the US universities.

The Humboldtian tradition was invented, but it was invented for good ethical and political purposes. Its "invention" was not arbitrary either. Humboldt's 1810 essay outlines values and aims for the university. Science and scholarship have intrinsic value and this is the proper motivation of their practitioners ("inner desire leads to science and research"). What is the origin of this intrinsic value of scientific and scholarly practices? Science and scholarship are driven by curiosity about the results of the open-ended process of science:

[I]t is a peculiarity of the higher scientific institutions that they always treat science as a problem that has still not been fully resolved and therefore remain constantly engaged in research, whereas the school deals with and teaches only finished and agreed-upon bits of knowledge. The relationship between teacher and students will therefore become quite different from what it was before. The former does not exist for the latter, both exist for science.

Humboldt thus maintained that basic research is itself practical in teaching, and particularly so in humanities. A consequence is that gymnasium (upper secondary school, high school) teachers must be well-versed in science and scholarship. Moreover, university education serves also the purpose of intellectual and moral development of individuals and collectives. People must first be well-informed

\footnotetext{
${ }^{5}$ This idea has found many practical expressions in different countries. For instance in Finland until 1988, the President of the Republic appointed university professors. As a general rule, Finnish Presidents followed the proposals of the universities, but there were exceptions and consequent speculations about political motivation.
} 
human beings and citizens and only then learn specific areas of study and professions. Although Humboldt writes about humanity and elsewhere refers to the idea of world citizenship, collective development is here understood first and foremost in terms of "the moral culture of the nation" (this background co-explains why the moral crisis caused by Nazism and the acquiescence of most German and Austrian academics was so deep and profound). The essence of science and scholarship lies cooperation, not in competition:

[S]ince the intellectual work within humanity flourishes only as cooperation, namely not merely in that one fills in what another lacks, but in that the successful work of one inspires the others, and that the general, original power that shines forth in the individual person only singly or deflected becomes visible to all, the internal organization of these institutions must bring forth and sustain a collaboration that is uninterrupted, constantly self-renewing, but unforced and without specific purpose.

There is no externally set purpose. Science in autonomous and should set its own purposes. University as an institution must be organised in such a fashion as to sustain cooperation toward realising the self-determined aims of sciences. The aims of science involve standards of excellence that are intrinsic to scientific and scholarly practices and exemplars for inspiration. This ideal may have never been realised in full, and at times it may have been marginalised or even crushed violently, but for a long while it had the capacity to define the direction of modernity and progress. Until the era of neoliberalism, many academic institutions embodied these principles.

\section{The idea of the university after the war}

The gist of the Humboldtian idea of the university is that it is in the interest of the state itself to guarantee the self-government of the university. The state should organise the autonomy of science and protect the university from political interventions and economic imperatives. Jürgen Habermas (1987a) has criticised German idealism for the view that a widely shared belief in the university idea (cf. Jaspers, 1960) must form the basis of modern science or scholarship. The university idea presupposes that sciences and humanities form an understandable whole, but this seems to be contradicted by the increasing complexity and differentiation of science and scholarship, corresponding to the functional differentiation of professions in the wider society. Student numbers are getting bigger (and bigger) and already for this reason the basis for a community-like university is being eroded. Commercial, vocational and administrative interests penetrate the university. Science research tends to be as hierarchical as Taylorist factories and private corporations. 
According to Habermas, these developments have made universities susceptible from within, as it were - to the profound transformation that we have seen since the 1970s and 1980s. Habermas downplays the fact that there is little if anything qualitatively new in these trends, which have been discussed by many observers since the 1860s and 1870s. On the other hand, he recognises that the idea of the university has served a counterhegemonic role. The idea of the university has been causally efficacious in many twists and turns of history: "[T]he utopian surplus inherent to the university idea also preserved a critical potential which from time to time could be revived for a renewal of the institutions" (1987a, p.14). This renewal contributed also to the external success of the institution:

The idea of the university contributed to the brilliance and the internationally incomparable success of German university science throughout the 19th century, and even up to the 1930s of our own century. (Habermas, 1987a, p.13)

In fact, organizations do embody ideas and principles. It is not necessary that all participants share the same idea for institutionalised practices to work. As Habermas (1979, pp. 102-3) himself has explained, the mechanisms and processes of collective learning through institutional developments are dissimilar from those of the growth of an individual. A diversity of individuals and their understandings may coexist within a shared institutional space. Although social structures are concept- and actiondependent, neither practical knowledge nor shared standards of excellence requires uniform belief in the same system of theoretical justification. The university idea is open to different interpretations and can be disputed from various perspectives. Moreover, the democratization of the university in the 1960s and 1970s facilitated debates and decision-making about values, aims and institutional arrangements.

I concur with the German idealists, however, that without some explicit values and purpose, the university is liable to becoming an empty shell, or "a soulless organism reduced to dead matter". Such an organization is all too easily harnessed to serve external interests. G.H. von Wright (1987, p.119) made this clear when he remarked that the strive for efficiency, which manifests itself for instance in various forms of quality control and auditing, is not in the interest of science itself. But who is defending the interests of science itself? The neoliberal transformation of the university may have been externally imposed, but once more, the acquiescence of most academics has been striking. Moreover, it is also true that belief systems such as NPM, with its various theoretical origins in economics, public choice theory and management studies, have emerged from within the university. Fields such as medicine focus almost exclusively on vocational training, take hierarchies in research laboratories for granted, and seek close collaboration with pharmaceutical industry. Many academics have played an active role in assuming positions of leadership in the neoliberal transformation and related processes of de-democratisation. 


\section{On the unity of all sciences and humanities}

Habermas understands modernisation in terms of functional differentiation, implying increasing complexity and differentiation of science and scholarship. He claims that sciences and humanities can no longer form an understandable whole. In the $20^{\text {th }}$ century, it is no longer possible to establish the "fiction of unity [...] through the totalizing power of philosophic reflection" (Habermas, 1987a, p.15). Habermas is right in the sense that neither empirically controlled science nor the essence of social life can be reduced to philosophy. It would be a speculative illusion to think otherwise. (Bhaskar, 1993, pp.81-89). But whereas Habermas concludes that only communicative rationality and the force of better arguments unite sciences and humanities, a new realist way of conceiving the unity of reality is evolving.

The new holism has developed from a growing interest in integrating different bits and pieces of knowledge across all levels of reality. The concepts of emergence and complexity provide the overall framework (as also many physicists have concluded, e.g. Laughlin \& Pines, 2000). The basic idea is simple and in accordance with empirical science. New relations and things can emerge; a new combination and organisation of elements may result in new properties and powers at the level of the whole. British emergentists started to develop these kinds of ideas already in the latenineteenth and early-twentieth centuries (for a review and good discussion, see O'Connor and Wong, 2015). Emergence occurs in time and thus the overall story is historical, starting with the Big Bang:

"[...] there is a single thread that runs through the whole story: the emergence, over the 13.8 billion years since the universe appeared, of more and more complex things. Complex things have many diverse components that are arranged in precise ways so that they generate new qualities. We call these new qualities emergent properties". (Christian, Brown, \& Benjamin, 2014, p.4).

The history of cosmos, life and human species seems to involve many layers of emergence, up to thirteen "scales of combogenesis" (Volk, 2017; cf. Christian, 2018). A new level emerges when things and relations at a prior level are combined and integrated, resulting in new things, relations and powers: from quarks to nuclei to atoms to molecules; from molecules to prokaryotic cells to eukaryotic cells to multicellular organisms; and from animal social groups to human tribal metagroups to agrovillages and to geopolitical states. The likely next layer is a qualitatively new social combination and integration on a planetary scale (Volk 2017, pp. 195-9).

Apart from emergence in nature, there is also emergence from nature. Emergence from nature concerns the level of intentional action and society (Bhaskar, 1998, especially pp.41-8). Roy Bhaskar argues that while the pre-existence of social forms 
is a necessary condition for any intentional act, reasons for actions can and must be causes. The causal powers of mind are explained in terms "synchronic emergent powers materialism" (for a well-known emergentist neuroscientific account of consciousness, see Sperry, 1980). The brain provides a basis, medium and vehicle of mental powers, but the powers of the human mind are not reducible to the brain. The properties and powers of the mind evolve in social contexts; and psychological states are relational and make references to social states and structures. Both can shape our brains. For all these reasons, social structures exist in a different way than natural structures and mechanisms. Social structures are activity- and concept-dependent and are thus usually much less stable and enduring than natural structures. The tendencies generated by particular social structures are not invariant across time and space.

The unity of reality is not a fiction. All sciences and humanities share the same object of study, namely the evolving cosmos, of which we humans and our culture and society form a part. Different faculties and disciplines focus on different layers of reality and their various aspects. The differentiated, layered and complex unity of reality can be studied from the point of view of different cognitive and moral interests such as theoretical, technical, hermeneutical, emancipatory and creative. ${ }^{6}$ While the meaning of truth lies in metaphorical correspondence to the way things really are, different theories of truth emphasise different criteria for making rational truthjudgements (e.g. coherence with evidence, expert opinion, pragmatic functioning, and making new realities). Science and scholarship are thus characterised by diversity and pluralism (cf. Rescher, 1993), but underlying all these diverse practices lies the differentiated, layered and increasingly complex reality of the evolving cosmos.

\section{The idea of the university in the 21st century global context}

As the theory of emergence and complexity indicates, our social development is an integral part of the evolution of the universe. Research and teaching practices are based on cooperation and scientific knowledge is public. Universities and researchers work together to achieve common goals. The ultimate goal of the university is to promote the common learning of mankind. We want to understand better the universe and how it functions, and also learn more about our place and possibilities in it. Practices include common goals, mutual efforts and assistance. Competition is limited to strive for excellence in terms that are intrinsic to scholarly practices.

Every university student should gain an understanding of the ultimate goal of the university and nature of science as an open-ended and pluralist research process. The

\footnotetext{
${ }^{6}$ Early Habermas (1987b) tried to theorise knowledge in terms of universal human interests. Here I am using the notion of different cognitive and moral interests only in a heuristic sense. Moreover, I have supplemented Habermas three interests with a scientific realist account of non-instrumentalist science (Niiniluoto, 1984, p.277) and Vicoan principle of verum ipsum factum - "truth itself is constructed" - which is often adequate in social sciences and humanities.
} 
German idealists were right in stressing that people must first be well-informed human beings and citizens and only then learn specific areas of study and, finally, professions. This is all the more important in the $21^{\text {st }}$ century, as we now know that scientific and industrial practices have been responsible for many evils. In our contemporary world, criticism of technologies and social practices and institutions is more important than ever. Collective learning takes place through ethical and political discussions and debates, for which universities provide a key site.

In the coming decades, the world will face unprecedented problems and difficulties. The global economic crisis 2008-9 and the ensuing euro crisis are just one indication of how the destinies of different countries and regions are increasingly intertwined. The prerequisites for everyday activities of all people are affected, either directly or indirectly, by how the world economy works - or does not. Global population growth will decline and, at the same time, the importance of economic growth must be reassessed. Many social scientists and philosophers, such as Martha Nussbaum in her book Not for Profit: Why Democracy Needs the Humanities (2016), have raised the importance of fostering humanistic education for the future of mankind. Compared to critical thinking and personal maturation, economic growth is of secondary importance. Education must be reconnected to the humanities in order to give students the capacity to be true democratic citizens of their countries and the world.

Perhaps the biggest immediate threat concerns the danger of a global military catastrophe and especially nuclear war (see Patomäki, 2008; 2018b). The expansion of the conflict between Russia and the West, as well as the confrontations in the Chinese Sea, show that the issues of global political economy and security have still not been organized on a sustainable basis. Global warming is part of a new geological era, Anthropocene. The influence of human science and culture is present everywhere on our planet. The expansion of human society has led, among other things, to the mass destruction of species, which continues at an accelerating pace.

We now realise that the biggest problems are created by our technological civilization itself. The concept of risk society developed by Ulrich Beck $(1992 ; 1999 ; 2012)$ refers to the second phase of modernization, where actors and movements begin to respond to the problems generated by science and technology and to the causal consequences of the first phase of modernization. Awareness of the great ethical and political choices facing us means that it is even more important to promote free and critical collective learning. The risk society is oriented towards the future. However, speaking about social risks is not just about the dangers and threats of the future. It also refers to new ethical, political and technological opportunities.

The concerns of a world risk society call for impartial testing of truth claims. The university is the place where aporias can be best resolved and contradictory statements about truth assessed freely on the basis of good arguments and 
independent evidence. The university can offer a unique space for criticism of the prevailing concepts and the development of new ones. It is precisely for this reason that the university has a crucial social critical and educative role in promoting the common learning of the whole of humanity. Making the future requires deep and autonomously formed knowledge based on free research. The main scientific institution - the university - must be self-governing or cease to be scientific.

Knowledge based on research has a number of direct and indirect practical implications for society. An increasingly large part of the population receives university education. Thus fair equality of citizens in terms of access to higher education is an essential part of social justice. Also teachers of lower educational institutions are trained at universities. The organization of university education is therefore absolutely crucial. What we currently have is an old-fashioned professional hierarchy where a thin set of career managers unilaterally control the entire academic life. The neoliberal university teaches a practical lesson to its members: democracy does not work and teacher-researchers or students are not trusted to make decisions. In contrast, the university idea involves free and equal members of the academia. If the objective of education is the empowerment and free growth of individuals as citizens of a democratic world community, theory and practice must be consistent.

\section{The autononomy of the university must be anchored in multi-spatial metagovernance}

The contemporary transformation of the university has been a worldwide process. The transformation has been enacted through transnational soft law, informal recommendations and agreements, consultancy reports, and simulations such as ranking-competition. Even the Bologna process is voluntary and based on informal agreements. (Lorenz, 2006) In spite of the "softness" of the legal and other instruments used, these processes have tended to override national legal and constitutional guarantees. For instance, the Finnish constitution $\$ 16$ guarantees the freedom of science, art, and higher teaching; $\$ 123$ declares that universities are selfgoverning, as specified by the law. The new fusion university Tampere 3 contradicts the basic tenets of these articles. It is owned by a foundation that is in effect controlled by the Technology Industries of Finland. Combining the former University of Tampere, Technical University of Tampere and Tampere Polytechnic (a school offering practical profession-oriented training), the Board of Tampere 3 does not include a single representative of researcher-teachers or students. A telling example of the current developments is how, in 2018, the Dean of the Faculty of Management and Business - the faculty includes such major social sciences as Politics and International Relations - was recruited from Cargotec, a globally operating largescale corporation making cargo-handling machinery for ships, ports, and terminals. 
The worldwide university transformation of the past few decades demonstrates the power of multi-spatial metagovernance (see Jessop, 2012; 2016). Metagovernance refers to attempts to govern the government and governance of social relations. Multi-spatiality describes the plurality of territorial area, social scales, networks and places that are involved in metagovernance. The processes of metagovernance are capable of shaping ideas about state interests, as the current repurposing of the university shows. States' interests have been reconstructed: they have ceased to guarantee the self-government and autonomy of the university.

In the prevailing economic imaginary, knowledge-based economy is believed to be the key to the competitiveness of states, and competition in the world markets is supposed to determine the prospects of states and their citizens' welfare (Sum \& Jessop, 2013). In business, competitiveness is typically envisaged in Darwinist terms of survival. Claims about existential threats legitimise exceptional measures (analogically to how securitisation works; see Wæver, 1995; Patomäki, 2015). Even when the quest for competitiveness is not framed in such extreme terms, competitiveness is assumed to have far-reaching consequences:

How well countries adapt to the Fourth Industrial Revolution (4IR) will determine whether they 'thrive' or 'stagnate' and could further divide workforces and increase social tensions, according to the latest version of the World Economic Forum's Global Competitiveness Report. Almost 40 years after its first annual assessment of the global economy, the Forum's 2018 report uses new methodology to understand the full impact of the 4IR, and finds factors including human capital, agility, resilience, openness and innovation becoming increasingly important. The new index measures 140 economies against 98 indicators, organized into 12 'pillars' or drivers of productivity, to determine how close the economy is to the ideal state or 'frontier' of competitiveness. (Whiting, 2018)

Economic performance is assessed in terms of various indices and benchmarking devices that subsequently drive policy (for simple neo-Keynesian criticism of the theoretical underpinnings of macro-competitiveness, see Krugman, 1994; 1996). Within this framework, various transnational actors - from consultancy-gurus and rankers to formal international organisations - operate at multiple spatial scales in setting standards and benchmarks for the universities. These standards and benchmarks rely mostly on theories and hypotheses associated with NPM, and on related ideas and concepts that are typically drawn from business practices or studies (e.g. the concept of "silo"; fashionable for a while, before a new fad arrives).

It thus seems clear that the idea of the university must be re-realised through interventions in the processes of multi-spatial metagovernance. Criticisms and alternative framings and imaginaries are required, to be fed into these processes. For 
instance, the idea of state competitiveness in the world markets is contradictory (Patomäki, 2005, ch 6; Patomäki, 2018, ch 6). Contradictions can be overcome by collective action and by building adequate common institutions. Something similar holds true for the universities as well. Instead of accepting heteronomous determination of their circumstances, the universities should collaborate to set standards and benchmarks in accordance with the idea of autonomous university. They should act in the spirit of world citizenship. Eventually, the autonomy of science and the freedom of the university from political interventions and economic imperatives ought to be established in international or cosmopolitan law.

\section{Conclusions}

It is no doubt true that the trends depicted by Habermas (1987a) are real. Science and scholarship have become increasingly complex and differentiated. Generations of scientists have been trained as technical specialists and often in hierarchical settings where the penetration of external interests is taken for granted. Moreover, during the last three to four decades, the university idea has been repudiated in terms of theories developed in economics, business and management studies and some social sciences. Even under these circumstances, the clear majority of scientists and scholars has typically been opposed to the prevailing direction of changes - while only relatively few have engaged in activism to defend the university.

In the absence of explicit values and purpose, the university has already become an empty shell, or "a soulless organism reduced to dead matter". This absence has to be absented. It is time to renew the idea of the university in the global context of the $21^{\text {st }}$ century. Theories of emergence and complexity show how it is possible to have a unified view of science and scholarship in the midst of all the diversity and pluralism. The world risk society and reflexive modernity require autonomous science and scholarship more than ever. Moreover, I have argued that in the contemporary world, the idea of the university can most plausibly be revived and developed further through interventions in the processes of multi-spatial metagovernance.

This raises the question of agency. As long as most governments are committed to developing their "competitiveness" by means of subjugating universities under the imperatives of "knowledge-based economy", they are unlikely to be interested in guaranteeing the self-government and autonomy of the university. The current university managers are similarly interested, above all, in ranking-performances and generating funds; and they are, at least primarily, keen to listen only to governments, external funders, corporations, consultants, and other transnational standard-setters.

On the other hand, not all universities and governments are alike. In spite of the powers of multi-spatial metagovernance and transnational investors, it remains 
possible to think and act otherwise. While reliance on selected governments and universities may be overoptimistic, they could make a difference if pushed and supported by an emerging transnational movement for the renewal of the university.

\section{References}

Ash, M. (2006). Bachelor of what, master of whom? The Humboldt myth and historical transformations of higher education in German-speaking Europe and the US. European Journal of Education, 41(2), 245-267.

Beck, U. (1992). Risk society: towards a new modernity. Transl. M.Ritter London: Sage.

Beck, U. (1999) World risk society. Cambridge: Polity Press.

Beck, U. (2012). Global risk society. In G.Ritzker (Ed.) Encyclopaedia of Globalization, vol. II. Oxford: Wiley-Blackwell, pp. 836-838.

Bhaskar, R. (1993). Dialectic. The pulse of freedom. London: Verso.

Bhaskar, R. (1998). The possibility of naturalism. A philosophical critique of contemporary human sciences. 3rd edition. London and New York: Routledge.

Canaan, J. \& Shuman, W. (2008). Higher education in the era of globalization and neoliberalism. In J.Canaan \& W.Shuman (Eds.), Structure and agency in the neoliberal university (pp. 1-28). London $\&$ New York: Routledge.

Christian, D. (2018). Origin story. A big history of everything. London: Allen Lane.

Christian, D., Brown, C. \& Benjamin, C. (2014). Big History. Between nothing and everything. New York: McGraw-Hill Education.

Gruening, G. (2001). Origin and theoretical basis of New Public Management. International Public Management Journal, 4(1), 1-25.

Habermas, J. (1979). Communication and the evolution of society. Transl. by T.McCarthy. Boston: Beacon Press.

Habermas, J. (1987a). The idea of the university: learning processes. Trans. J.Blazek. New German Critique, 41(Spring-Summer), pp. 3-22.

Habermas, J. (1987b). Knowledge \& human interests. Transl. J. Shapiro. Cambridge: Polity Press [originally published in 1968].

Jaspers, K. (1960). The idea of the university. Trans. H.A.T. Reiche \& H.F. Vanderschmidt. London: Peter Owen.

Jessop, B. (2012). Obstacles to a world state in the shadow of the world market. Cooperation and Conflict, 47(2), pp. 200-219. 
Jessop, B. (2016). Territory, politics, governance and multispatial metagovernance. Territory, Politics, Governance, 4(1), pp. 8-32.

Krugman, P. (1994). Competitiveness: a dangerous obsession. Foreign Affairs, 73(2), pp. $28-44$.

Krugman, P. (1996). Making sense of the competitiveness debate. Oxford Review of Economic Policy, 12(3), pp. 17-25.

Laughlin, R. and Pines, D. 2000. The Theory of Everything. PNAS, 97(1), pp. 28-31.

Lorenz, C. (2006). Will the universities survive the European Integration? Higher Education Policies in the EU and in the Netherlands before and after the Bologna Declaration. Sociologia Internationalis, 44(4), pp. 123-151. The quotation is from an earlier version, available at: https://web.archive.org/web/20160327102818/http://www.lsa.umich.edu/UMICH/ces/Home/ Resources/Michigan\%20Paper\%20Series/Lorenz_Will_Universities_Survive.pdf.

Mittelman, J. (2016). Global governance and universities: the power of ideas and knowledge. Globalizations, 13(5), 608-621.

Mittelman, J. (2018). Implausible dream. The world-class university and repurposing of higher education. Princeton, NJ: Princeton University Press.

Niiniluoto, I. (1984). Tiede, filosofia ja maailmankatsomus [Science, philosophy and worldview]. Helsinki: Otava.

Nussbaum, M. (2016) Not for profit: why democracy needs the humanities. Updated edition. Princeton, NJ: Princeton University Press.

O'Connor, T. and Wong, H. (2015). Emergent properties. The Stanford encyclopedia of philosophy (Summer 2015 Edition). E.Zalta (Ed.), available at https://plato.stanford.edu/archives/sum2015/entries/properties-emergent/.

Patomäki, H. (2005). Yliopisto oyj. tulosjohtamisen ongelmat - ja vaihtoehto [University inc. The problems of new public management - and an alternative]. Helsinki: Gaudeamus.

Patomäki, H. (2008). The political economy of global security. War, future crises and changes in global governance. London and New York: Routledge.

Patomäki, H. (2015). Absenting the absence of future dangers and structural transformations in securitization theory. International Relations, 29(1), pp. 128-135.

Patomäki, H. (2018a). Reflexivity of anticipations in economics and political economy. In R.Poli (Ed.) Handbook of anticipation. theoretical and applied aspects of the use of future in decision making. Springer: Cham, first online December 2018, DOI: https://doi.org/10.1007/978-3-31931737-3_16-1; print edition forthcoming in 2020.

Patomäki, H. (2018b). Disintegrative tendencies in global political economy: exits and conflicts. London and New York: Routledge. 
Rescher, N. (1993). Pluralism. Against the demand for consensus. Oxford: Clarendon Press.

Sayer, A. (2011). Why things matter to people. Social science, values and ethical life. Cambridge: Cambridge University Press.

Shaikh, A. (2016). Capitalism: Competition, Conflict, Crisis. Oxford: Oxford University Press.

Soros, G. (2013). Fallibility, reflexivity, and the human uncertainty principle. Journal of Economic Methodology, 20(4), pp. 309-329.

Sperry, R. (1980). Mind-brain interaction: mentalism, yes; dualism, no. Neuroscience, 5(2), pp.195-206.

Sum, N.L. \& Jessop, B. (2013). Competitiveness, the knowledge-based economy and higher education. Journal of the Knowledge Economy, 4(1), 24-44.

Volk, T. (2017). Quarks to culture. How we came to be. New York: Columbia University Press.

Von Wright, G. (1987). Tiede ja ihmisjärki ["Science and human reason"]. Transl. from Swedish by A. Leikola. Helsinki: Otava.

Wæver, O. (1995). Securitization and desecuritization. In R.Lipschutz (Ed.) On security. New York: Columbia University Press, pp. 46-86.

Whiting, K. (2018). These are the world's most competitive economies. World Economic Forum website 16 Oct 2018, available at https://www.weforum.org/agenda/2018/10/most-competitiveeconomies-global-competitiveness-report-2018/.

Heikki Patomäki is a professor of world politics at the University of Helsinki and a visiting fellow at the University of Cambridge (in 2019). Previously he has worked in Australia, Japan and UK. Patomäki's research interests focus on philosophy and methodology of social sciences, political economy and economic theory, futures studies, peace research and global political theory.

Patomäki's books in English include Disintegrative Tendencies in Global Political Economy: Exits and Conflicts (Routledge, 2018); The Great Eurozone Disaster: From Crisis to Global New Deal (Zed Books, 2013); The Political Economy of Global Security. War, Future Crises and Changes in Global Governance (Routledge, 2008); and After International Relations. Critical Realism and the (Re)Construction of World Politics (Routledge 2002). 